\title{
Young Stand Thinning and Diversity Study: Response of Songbird Community One Decade Post-Treatment
}

Open-File Report 2009-1253 



\section{Young Stand Thinning and Diversity Study: Response of Songbird Community One Decade Post-Treatment}

By Joan Hagar, U.S. Geological Survey, and Cheryl Friesen, U.S. Forest Service

Open-File Report 2009-1253

U.S. Department of the Interior

U.S. Geological Survey 


\section{U.S. Department of the Interior \\ KEN SALAZAR, Secretary}

\section{U.S. Geological Survey \\ Marcia K. McNutt, Director}

U.S. Geological Survey, Reston, Virginia: 2009

For more information on the USGS-the Federal source for science about the Earth, its natural and living resources, natural hazards, and the environment, visit http://www.usgs.gov or call 1-888-ASK-USGS.

For an overview of USGS information products, including maps, imagery, and publications, visit http://www.usgs.gov/pubprod

To order this and other USGS information products, visit $h$ ttp://store.usgs.gov

Suggested citation:

Hagar, Joan, and Friesen, Cheryl, 2009, Young stand thinning and diversity study: Response of songbird community one decade post treatment: U.S. Geological Survey Open-File Report 2009-1253, 20 p.

Any use of trade, product, or firm names is for descriptive purposes only and does not imply endorsement by the U.S. Government.

Although this report is in the public domain, permission must be secured from the individual copyright owners to reproduce any copyrighted material contained within this report. 


\section{Contents}

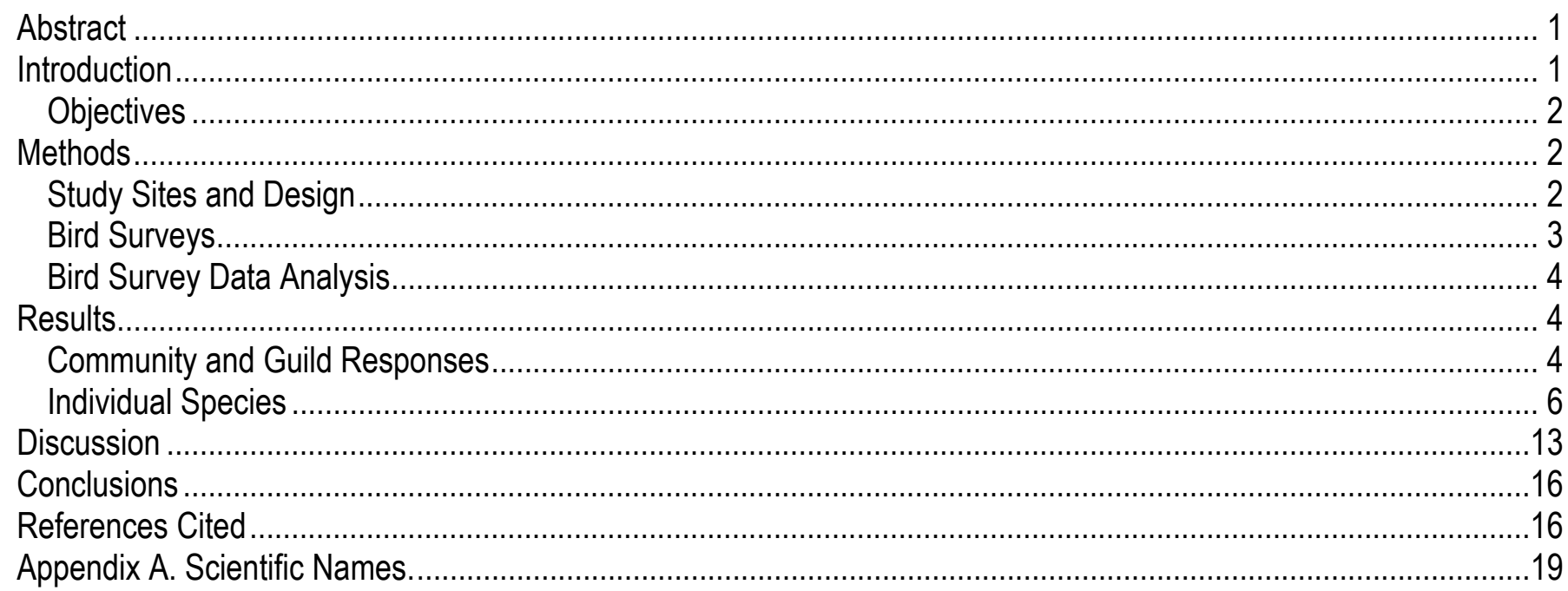

\section{Figures}

Figure 1. Comparison of species richness with 95-percent confidence interval $(A)$ among four silvicultural treatments in 2006 and 2007, and (B) over 8 cumulative years of bird surveys (1992 and 1993 were pre-treatment) in four silvicultural treatments in young Douglas-fir stands Willamette National Forest, Oregon

Figure 2. Comparison of median density (birds/40 ha) of cavity-nesting bird species (A) in 2006 and 2007, and (B) over 8 cumulative years of bird surveys (1992 and 1993 were pre-treatment) in four silvicultural treatments in young Douglas-fir stands, Willamette National Forest, Oregon

Figure 3. Comparison of (A) median density (birds/40 ha; with 90-percent confidence interval) of neotropical migrant bird species in 2006-07, and (B) mean density of neotropical migrant birds over 8 cumulative years of bird surveys (1992 and 1993 were pre-treatment) in four silvicultural treatments in young Douglas-fir stands, Willamette National Forest, Oregon.

Figure 4. Comparison of density (birds/40 ha; with 90-percent confidence interval) in 2006-07 (i) and over 8 cumulative years of bird surveys (ii) for bird species with a positive, linear response to thinning in four silvicultural treatments in young Douglas-fir stands. Willamette National Forest, Oregon.

Figure 5. Comparison of density (birds/40 ha; with 90-percent confidence interval) in 2006-07 (i) and over 8 cumulative years of bird surveys (ii) for bird species showing a positive, threshold response to thinning in four silvicultural treatments in young Douglas-fir stands, Willamette National Forest, Oregon

Figure 6. Comparison of density (birds/40 ha; with 90-percent confidence interval) in 2006-07 (i) and over 8 cumulative years of bird surveys (ii) for bird species showing a negative response to thinning in four silvicultural treatments in young Douglas-fir standsWillamette National Forest, Oregon.

\section{Tables}

Table 1. Thinning treatments applied to 30- to 40-year-old conifer stands in the Young Stand Thinning and Diversity Study, Cascade Range, Oregon

Table 2. Results of repeated measures ANOVA to test for effect of four thinning treatments on species richness and bird density approximately one decade after thinning in young Douglas-fir stands in the Willamette National Forest, Oregon, 2006-07.

Table 3. Frequency of occurrence and (total number of observations) for uncommon species observed predominantly in thinned stands, Young Stand Thinning and Diversity Study, Cascade Range, Oregon. 


\section{Conversion Factors}

\begin{tabular}{|c|c|c|}
\hline Multiply & By & To obtain \\
\hline centimeter $(\mathrm{cm})$ & 0.3937 & inch (in.) \\
\hline meter $(\mathrm{m})$ & 1.094 & yard (yd) \\
\hline hectare (ha) & 2.471 & acre \\
\hline
\end{tabular}




\title{
Young Stand Thinning and Diversity Study: Response of Songbird Community One Decade Post-Treatment
}

\author{
By Joan Hagar, U.S. Geological Survey, and Cheryl Friesen, U.S. Forest Service
}

\begin{abstract}
The response of songbird assemblages to commercial thinning is likely to change as vegetation develops over time after thinning. The influence of thinning intensity and pattern on the timing of transitions in bird community composition following thinning is of interest to managers when a goal is to maintain diversity and accelerate the development of late-seral forest structure. We investigated changes in the composition of songbird assemblages and density of individual species from 2 years before to 12 years after experimental thinning of 40-year-old stands dominated by Douglas-fir (Pseudotsuga menziesii) in the Oregon Cascades. Species richness, and density for five species and the neotropical migrant group were greater in thinned than in unthinned control stands over all posttreatment years of the study. Similarly, three species maintained a negative response to thinning over the post-treatment period. The initial positive influence of thinning was no longer in evidence a decade after harvest for five species. Of seven species with an initial negative response to thinning, three indicated recovery towards pre-treatment densities by the end of the most recent post-treatment survey. Our study is one of the first to document long-term effects of commercial thinning on forest songbird assemblages in the Pacific Northwest.
\end{abstract}

\section{Introduction}

Young plantations that have developed after clear-cutting currently dominate millions of acres of forested landscapes in western Oregon and Washington (DeBell and others, 1997). Young, managed forests often have simplified structure and typically lack the range and diversity of structural features for wildlife found in natural forests (Hansen and others, 1991; Carey, 1998). Furthermore, young stands that have regenerated following clear-cutting may never develop the structural features characteristic of present old-growth (Tappeiner and others, 1997a; Poage, 2000). Current management goals for young stands on public lands include the incorporation of structural characteristics typical of natural young forests, such as well developed understory and diverse plant species composition, and more rapid development of late successional habitat (Forest Ecosystem Management Assessment Team, 1993). The potential of commercial thinning to increase structural diversity in managed conifer stands and redirect the developmental trajectory of young stands towards greater structural diversity has gained recognition over the past decade (Spies and others, 1991; DeBell and others, 1997; Tappeiner and others, 1997b; Carey and others, 1999). Alternative intensities and patterns of thinning are being examined as a means of accomplishing management goals to promote the development of old-growth structure over the long term. Although managers are beginning to use thinning to manipulate habitat for wildlife, more information is needed to determine guidelines for residual tree densities and patterns for thinning prescriptions to enhance wildlife diversity. In particular, little information is available on the long-term response of vegetation and wildlife to alternative thinning treatments. 
The immediate response of songbird assemblages to thinning in earlier survey periods of this study (Hagar and others, 2004) and in other studies in western conifer forests generally has been increases in the density or abundance of species associated with open canopy conditions, decreases in those associated with dense, closed conifer canopy, but with an overall increase in species richness (Hagar and others, 1996; Haveri and Carey, 2000; Hayes and others, 2003). As vegetation develops over time after thinning, the responses of individual bird species to thinning is likely to change. For example, thinning is expected to accelerate the development of large overstory trees with well-developed canopies (Garman and others, 2002), which may improve habitat for those species associated with closed-canopy conditions even though they had an initial negative response to thinning. Similarly, abundance of shrub-associated bird species would be expected to track the initial positive response of understory vegetation to a reduction of overstory cover, and any subsequent fading of response as the canopy closes over time. The influence of the intensity and pattern of thinning on the timing of these transitions in bird abundance and community composition following thinning has not been well studied, but may be of interest to managers that are striving to maintain diversity and accelerate the development of late-seral forest structure.

\section{Objectives}

The Cascade Center for Ecosystem Management initiated the Young Stand Thinning and Diversity Study (hereafter Young Stand Study) on the Willamette National Forest to investigate the effects of several management regimes of young stands on vegetation and wildlife. This study investigated the initial response of vegetation and wildlife to alternative thinning practices (Garman 2000; Hagar and others, 2004; Davis and others, 2007; Davis and Puettman, in press) and continues to monitor long-term responses as forest structure changes over time. The broad objective of the wildlife component of the project is to contribute to an understanding of the responses of wildlife species to development of stands under different thinning regimes. Our long-term goal in this study is to determine the timing and structural conditions that define thresholds of habitat occupancy for forest songbird species. Here, we report on the composition of songbird assemblages and the density of individual species in the Young Stand Study approximately one decade after the initial thinning treatments were applied.

\section{Methods}

\section{Study Sites and Design}

Study sites are in the Willamette National Forest on the west slope of the central Oregon Cascade Range. The study design was based on four silvicultural treatments applied to 30- to 40-yearold stands, a typical age for the first commercial thinning entry (table 1). All four treatments were replicated in each of four geographic blocks (one block each in McKenzie and Blue River Ranger Districts, and two blocks in Oakridge Ranger District; total of 16 treatment areas). Treatment areas averaged 30 ha (75 acres). Treatments were randomly assigned to stands within each block. Thinning was done at different times for each District, but harvests were completed between January 1995 and September 1997. In 2001, snags were created in each of the 16 treatment areas in the study by topping with a chainsaw and innoculating with heartrot fungus (Phellinus pini). The target density for each unit was 2.5 snags ( $>30.5 \mathrm{~cm}$ [12 in.] diameter at breast height [dbh]) per ha (1 snag per acre). 
Table 1. Thinning treatments applied to 30- to 40-year-old conifer stands in the Young Stand Thinning and Diversity Study, Cascade Range, Oregon.

\begin{tabular}{|l|l|l|}
\hline \multicolumn{1}{|c|}{ Treatment } & \multicolumn{1}{|c|}{ Tree density } & \multicolumn{1}{c|}{ Associated hypothesis } \\
\hline Light thin (LT) & 110 trees per acre (271/ha) & $\begin{array}{l}\text { Standard silivicultural practices will produce stand structure } \\
\text { and composition more similar to old growth over time more } \\
\text { quickly than doing nothing at all. }\end{array}$ \\
\hline $\begin{array}{l}\text { Light thin with gaps } \\
\text { (LG) }\end{array}$ & $\begin{array}{l}110 \text { trees per acre }(271 / \mathrm{ha}) ; \\
\text { and } 20 \text { percent of the stand } \\
\text { in } 0.5 \text {-acre }(0.2 \text { ha) } \\
\text { openings }\end{array}$ & $\begin{array}{l}\text { Standard silivicultural practices modified to include gaps } \\
\text { will produce stand structure and composition more similar } \\
\text { to old growth over time more quickly than a standard } \\
\text { silvicultural thinning. }\end{array}$ \\
\hline Heavy thin (HT) & $\begin{array}{l}50 \text { trees per acre (123 trees } \\
\text { per ha) }\end{array}$ & $\begin{array}{l}\text { Rapid growth of trees and associated second story in } \\
\text { response to open canopy will produce stand structure and } \\
\text { composition more similar to old growth over time more } \\
\text { quickly than any other treatment. }\end{array}$ \\
\hline $\begin{array}{l}\text { Unthinned Control } \\
\text { (CO) }\end{array}$ & $>200$ trees per acre & $\begin{array}{l}\text { Untreated stands will take the longest time to produce stand } \\
\text { structure and composition similar to old growth, if at all. }\end{array}$ \\
\hline
\end{tabular}

All sites were within the western hemlock (Tsuga heterophylla) zone (Franklin and Dyrness, 1988) and were dominated by Douglas-fir (Pseudotsuga menziesii). Western hemlock and western redcedar (Thuja plicata) also were common. Hardwoods such as bigleaf maple (Acer macrophyllum) and giant chinquapin (Chrysolepis chrysophylla) comprised a minor component of the overstory. Dominant understory species included sword fern (Polystichum munitum), salal (Gaultheria shallon), vine maple (Acer circinatum), Oregon grape (Mahonia nervosa), and Pacific rhododendron (Rhododendron macrophyllum). Elevation of study sites ranged from 440 to $900 \mathrm{~m}$; elevation of stands within a block generally differed by less than $240 \mathrm{~m}$. Stand sizes ranged from 19 to 30 ha (47 to 74 acres) for thinned stands, and as many as 53 ha (131 acres) for control stands.

\section{Bird Surveys}

Bird surveys were conducted in eight breeding seasons, over a period of 15 years. Pre-treatment bird surveys were conducted during the spring of 1992 and 1993. Surveys to assess the initial response of birds after treatment were conducted in May-June 1997-99, and 2001 (Hagar and others, 2004). The third phase of surveys, which is the focus of this report, was conducted in May-July 2006 and 2007.

Songbirds were surveyed using standard point count methodology (Ralph and others, 1995) at stations established in each stand during the first post-treatment bird survey in 1997. Birds were surveyed at point count stations during four visits to each stand between mid-May and early July each year. Observers recorded the species and distance to each bird detected during 10-minute count periods at each station. Surveys were conducted between 30 minutes before and 6 hours after sunrise. We did not conduct surveys during periods of heavy rain or strong wind because bird activity is suppressed and the observer's ability to detect birds is reduced under these conditions. 


\section{Bird Survey Data Analysis}

Response variables were species richness and estimates of breeding density (birds/40 ha) for species with sufficient numbers of detections (present in $>30$ percent of the 32 stand $\times$ year experimental units). We also assessed treatment effects for cavity nesters as a group and for neotropical migrants as a group. Species included in the cavity-nesting group were Chestnut-backed Chickadee, Red-breasted Nuthatch, Brown Creeper, Red-breasted Sapsucker, Hairy Woodpecker, Northern Flicker, and Pileated Woodpecker. Species included in the neotropical migrant group were Common Nighthawk, Rufous Hummingbird, Black-throated Gray Warbler, Western Wood-pewee, Olive-sided Flycatcher, Pacific-slope Flycatcher, Hammond's Flycatcher, Swainson's Thrush, Hermit Thrush, Warbling Vireo, Hermit Warbler, MacGillivray's Warbler, Wilson's Warbler, Western Tanager, and Black-headed Grosbeak. Although assessing the response of neotropical migrants as a group has no ecological basis because of the diversity of habitat associations represented, the U.S. Forest Service (USFS) currently classifies these species as a unit for management purposes, and therefore requested a group-level analysis of response to treatment.

We calculated bird density for each stand in a single year as the number of birds detected divided by the effective area surveyed, where the numerator and the denominator are summed across repeated visits to each station within each stand within a year (Hagar and others, 2004). To estimate the effective area surveyed for each species at every point count, we used a detectability model that adjusted the effective area surveyed for every bird observation to average detectability conditions (Beavers and Ramsey, 1998). We assumed that three factors influenced detectability: the observer, the number of minutes past sunrise, and tree density. Seven models were developed to predict effective area at average detectability conditions for each species: three univariate (single-factor) models, three two-factor models, and the model incorporating all three factors. We used Akaike's information criterion (AIC) to select the best model for each species (Burnham and Anderson, 1998).

To account for the correlation between data collected in the same stands over time, we used repeated measures ANOVA for a completely randomized block design (SAS Institute, 2003) to test for effects of thinning treatments on species richness and bird density in 2006 and 2007. We used an $\alpha=$ 0.10 to determine a treatment effect (table 2) because we were concerned about failing to detect a true effect (Type II error) as a result of our small sample size. We used confidence intervals to determine which treatments differed only if the $P$-value from the ANOVA was significant $(<0.10)$. The use of confidence intervals in combination with $P$-values allowed us to assess the ecological importance of statistically significant effects of thinning treatments, while reducing the possibility of making a Type I error (Steidl and others, 1997; Di Stefano, 2004).

\section{Results}

\section{Community and Guild Responses}

In 2006 and 2007, approximately 10-12 years post-thinning, bird species richness was greater in heavy thin (HT) and light thin with gap (LG) treatments than in control (CO) by an average of about four species per stand (fig. 1, table 2). Species richness in light thin (LT) was intermediate between CO and the more intensively thinned HT and LG treatments (table 2). Species richness was not significantly different among the three thinning treatments. The pattern of greater species richness in thinned stands was consistent over the 6 post-treatment survey years of the study (fig. 1B). 

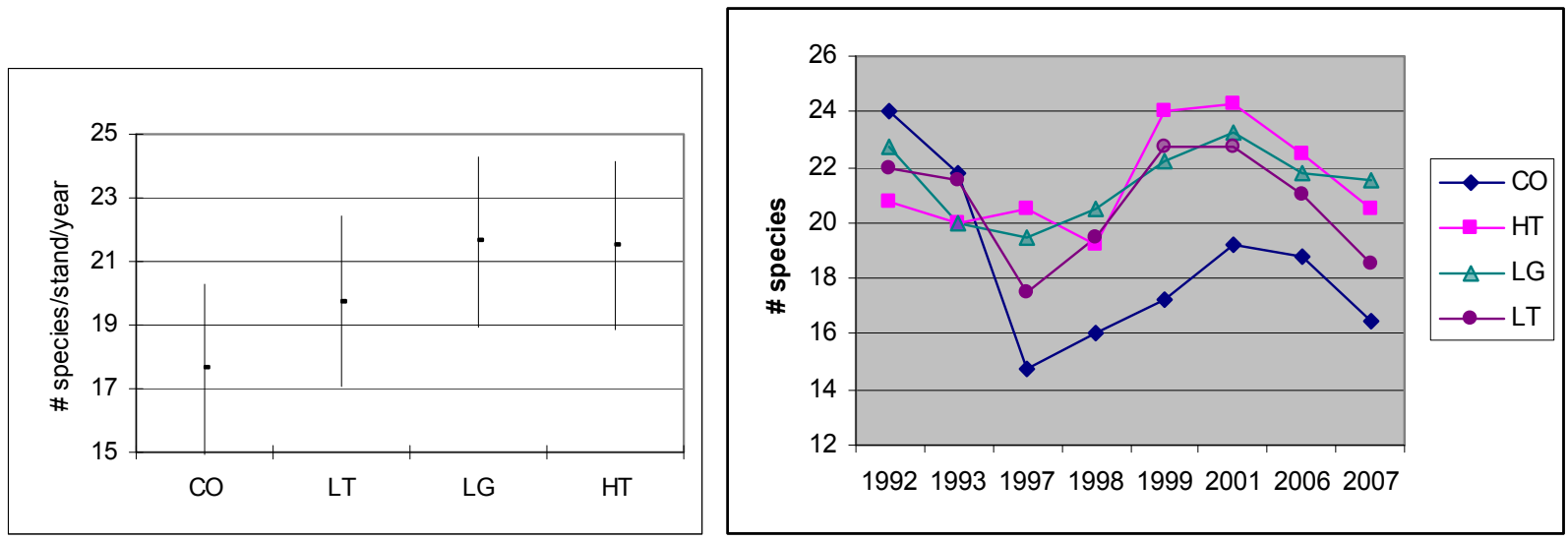

Figure 1. Comparison of species richness with 95-percent confidence interval $(A)$ among four silvicultural treatments in 2006 and 2007, and (B) over 8 cumulative years of bird surveys (1992 and 1993 were pre-treatment) in four silvicultural treatments in young Douglas-fir stands Willamette National Forest, Oregon. $[\mathrm{CO}$, unthinned controls, LT, light thin, LG, light thin with gaps, and heavy thin $(\mathrm{HT})]$.

Table 2. Results of repeated measures ANOVA to test for effect of four thinning treatments on species richness and bird density approximately one decade after thinning in young Douglas-fir stands in the Willamette National Forest, Oregon, 2006-07.

[Thinning treatment: CO, control; LT, light thin; LG, light thin with gaps; HT, heavy thin. $\operatorname{Pr}>\mathrm{F}$ is the probability associated with the null hypothesis of no treatment effect]

\begin{tabular}{|c|c|c|c|c|c|c|}
\hline \multirow[b]{3}{*}{ Response } & \multicolumn{4}{|c|}{ Thinning treatments } & \multirow{2}{*}{$\begin{array}{l}\text { F-Value } \\
\text { (3,9 DF) }\end{array}$} & \multirow[b]{2}{*}{$\mathrm{Pr}>\mathrm{F}$} \\
\hline & $\mathrm{CO}$ & LT & LG & HT & & \\
\hline & & & & & & \\
\hline $\begin{array}{l}\text { Species Richness } \\
\text { (number species/stand) }\end{array}$ & 17.6 & 19.7 & 21.6 & 21.5 & 3.46 & 0.064 \\
\hline \multicolumn{7}{|l|}{ Bird density (birds/40 ha) } \\
\hline Cavity Nesting Birds & 2.8 & 3.3 & 3.7 & 3.6 & 10.83 & 0.002 \\
\hline Neotropical Migrants & 4.2 & 4.7 & 4.8 & 4.9 & 26.78 & $<0.0001$ \\
\hline American Robin & 0.5 & 1.0 & 1.3 & 1.0 & 4.77 & 0.030 \\
\hline Chestnut-backed Chickadee & 2.1 & 2.4 & 2.7 & 2.9 & 2.70 & 0.108 \\
\hline Dark-eyed Junco & 1.7 & 3.2 & 3.4 & 3.8 & 21.94 & 0.0002 \\
\hline Golden-crowned Kinglet & 4.1 & 3.2 & 2.7 & 2.0 & 3.71 & 0.055 \\
\hline Hammond's Flycatcher & 1.6 & 3.2 & 2.5 & 2.3 & 3.16 & 0.078 \\
\hline Hermit Thrush & 1.6 & 0.3 & 0.4 & 0.6 & 7.56 & 0.008 \\
\hline Hermit Warbler & 3.2 & 3.6 & 3.6 & 3.4 & 6.84 & 0.011 \\
\hline MacGillivray's Warbler & 0.1 & 2.2 & 3.3 & 3.4 & 77.38 & $<0.0001$ \\
\hline Pacific-slope Flycatcher & 2.8 & 1.6 & 1.2 & 0.5 & 17.66 & 0.0004 \\
\hline Red-breasted Nuthatch & 1.0 & 1.2 & 1.4 & 1.5 & 1.62 & 0.253 \\
\hline Steller's Jay & 0.9 & 1.2 & 1.1 & 1.4 & 1.50 & 0.280 \\
\hline Swainson's Thrush & 2.2 & 1.8 & 2.5 & 2.7 & 6.90 & 0.010 \\
\hline Western Tanager & 1.6 & 2.7 & 2.5 & 3.0 & 17.24 & 0.0005 \\
\hline Winter Wren & 3.3 & 2.9 & 1.9 & 1.3 & 11.15 & 0.002 \\
\hline
\end{tabular}


Density of all cavity-nesting species combined also was greater in thinned treatments than in CO in 2006 and 2007 (fig. 2A, table 2). Differences in median density ranged from 12 birds/40 ha more in LT than CO, to 24 birds/40 ha more in LG compared to CO. Among the treated stands, LG averaged significantly greater density of cavity-nesting species than LT (based on lack of overlap of confidence intervals with means). Density of cavity-nesting species did not show a consistent response to treatment until approximately 5 years post-treatment in 2001(fig. 2B), when snags were created in all stands.

Density of all neotropical migratory species combined was greater in thinned treatments than in $\mathrm{CO}$ (fig. 3A, table 2). The median density of neotropical migrants was more than twice as great in the $\mathrm{HT}$ as in CO. Among thinning treatments, the median density in HT was about 25 birds/40 ha greater than in LT, but densities in LG and HT were similar.

Density of neotropical migrants in $\mathrm{CO}$ has been consistently as low as or lower than density in thinned stands throughout the post-treatment phase of the study (fig. 3B). However, the difference in density among thinning treatments has not been consistent among survey years. In the first posttreatment years (1997-98), densities were highest in LT and lowest in HT. In 1991 and 2001, densities in HT and LT were similar. The most recent survey years (2006-07) show significantly greater density in HT than LT (fig. 3A). These trends probably are largely driven by the most abundant species in this group: Hermit Warbler, Western Tanager, and Hammond's Flycatcher. Western Tanager has had the highest density in HT since 2001, and has been increasing in abundance since 1999 (fig. 4.B.ii). Hermit Warbler has had higher density in LT than HT since 1999, and density since 1999 has been lower than in pre-treatment years (fig. 5.B.ii). 2007 was the first year since 1999 that post-treatment density of Hermit Warbler regained pre-treatment level (in LG only).

\section{Individual Species}

Of the 14 species for which we were able to calculate density in 2006 and 2007, we detected a difference in the density of 11 species among treatments. The density of seven species was greater in thinned than $\mathrm{CO}$ stands. The density of two of these species increased linearly with thinning intensity (figs. 4A-4B). Five species that had greater densities in thinned than $\mathrm{CO}$ stands differed in density among thinning intensities, indicating possible threshold effects of thinning (figs. 5A-5E). The density of four species was negatively associated with thinning (figs. 6A-D). We did not detect a difference in density among treatments for three species: Steller's Jay, Chestnut-backed Chickadee, and Red-breasted Nuthatch. 


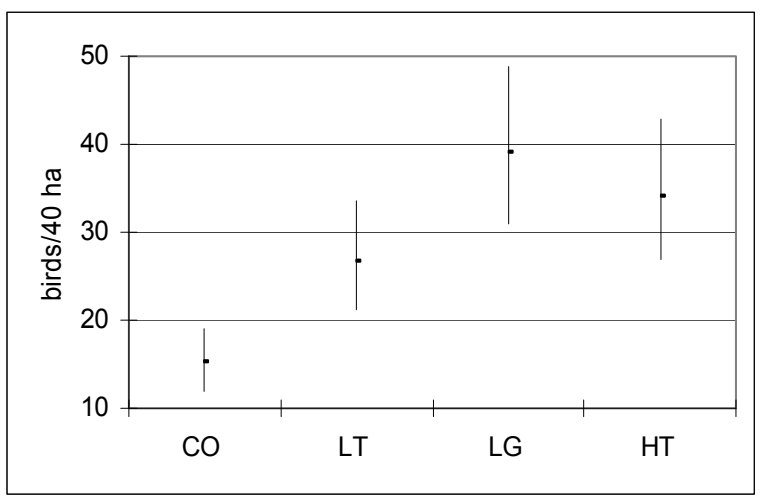

A.

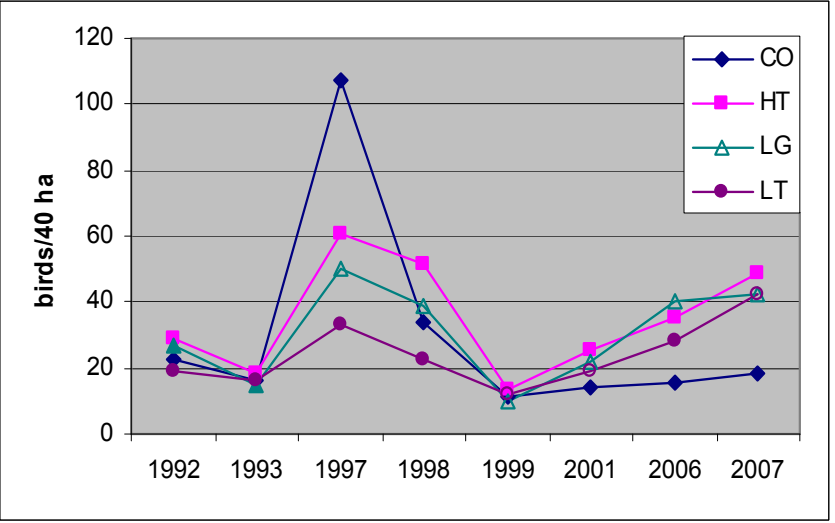

B.

Figure 2. Comparison of median density (birds/40 ha) of cavity-nesting bird species (A) in 2006 and 2007, and (B) over 8 cumulative years of bird surveys (1992 and 1993 were pre-treatment) in four silvicultural treatments in young Douglas-fir stands, Willamette National Forest, Oregon. [CO, unthinned controls, LT, light thin, LG, light thin with gaps, and heavy thin (HT)].
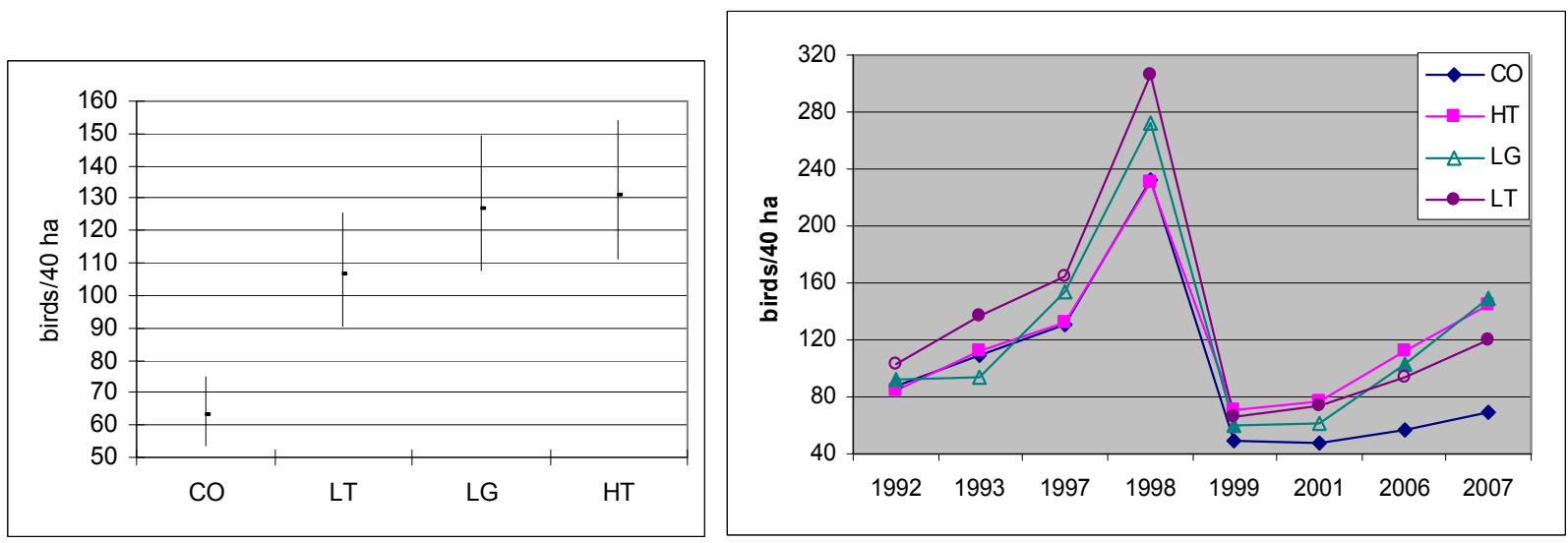

A

Figure 3. Comparison of $(A)$ median density (birds/40 ha; with 90-percent confidence interval) of neotropical migrant bird species in 2006-07, and (B) mean density of neotropical migrant birds over 8 cumulative years of bird surveys (1992 and 1993 were pre-treatment) in four silvicultural treatments in young Douglas-fir stands, Willamette National Forest, Oregon. See text for species included in neotropical migrant group. [CO, unthinned controls, LT, light thin, LG, light thin with gaps, and heavy thin (HT)]. 
A. Dark-eyed Junco
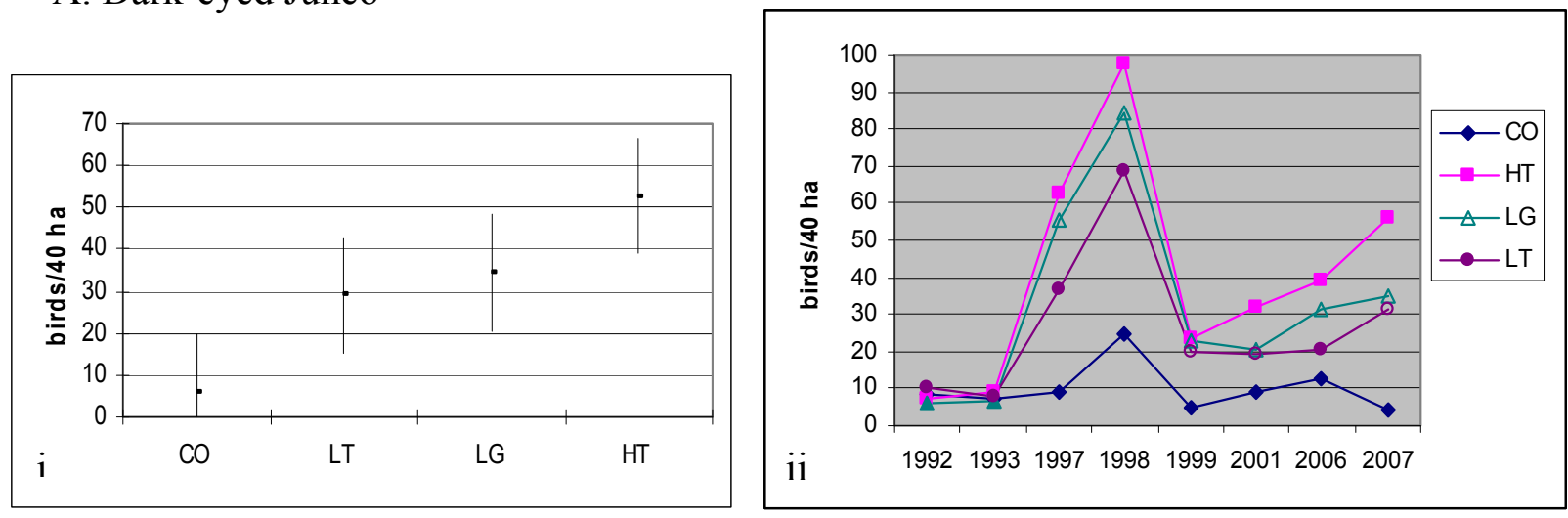

B. Western Tanager
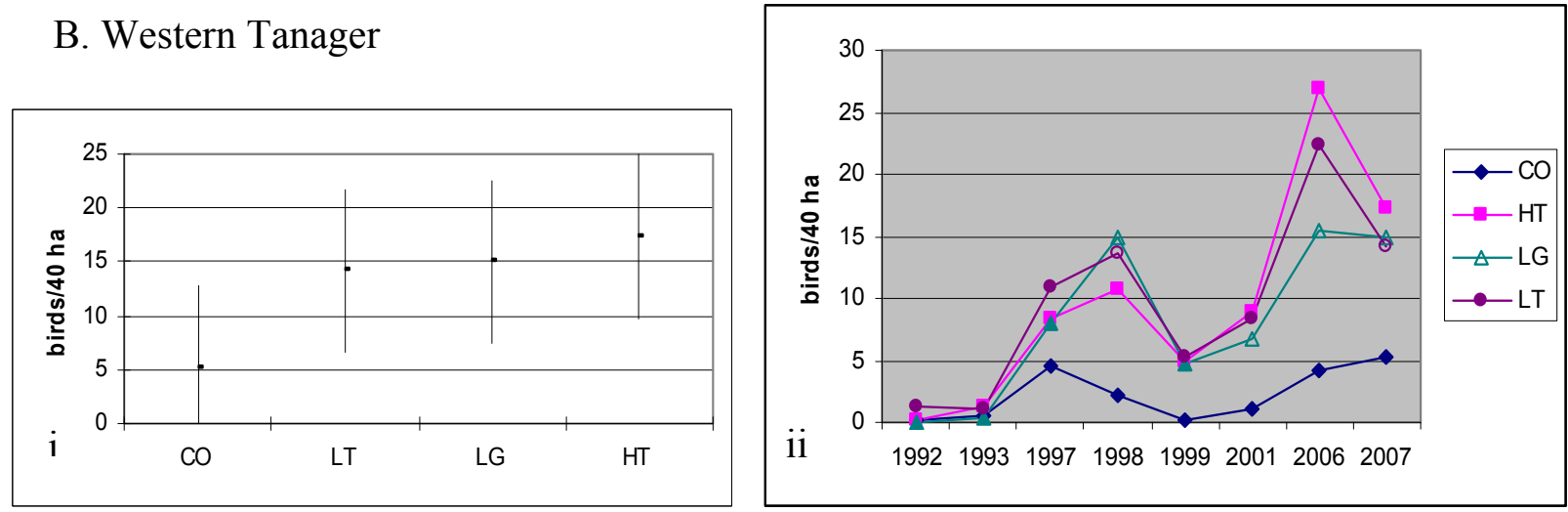

Figure 4. Comparison of density (birds/40 ha; with 90-percent confidence interval) in 2006-07 (i) and over 8 cumulative years of bird surveys (ii) for bird species with a positive, linear response to thinning in four silvicultural treatments in young Douglas-fir stands. Willamette National Forest, Oregon. [CO, unthinned controls, LT, light thin, LG, light thin with gaps, and heavy thin $(\mathrm{HT})$ ]. 
A. Hammond's Flycatcher

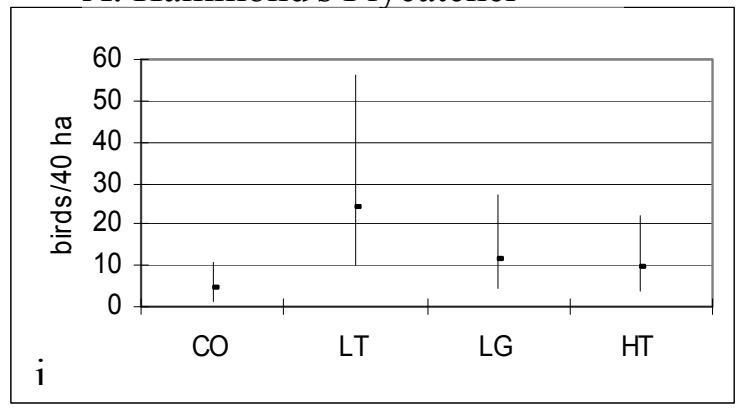

B. Hermit Warbler

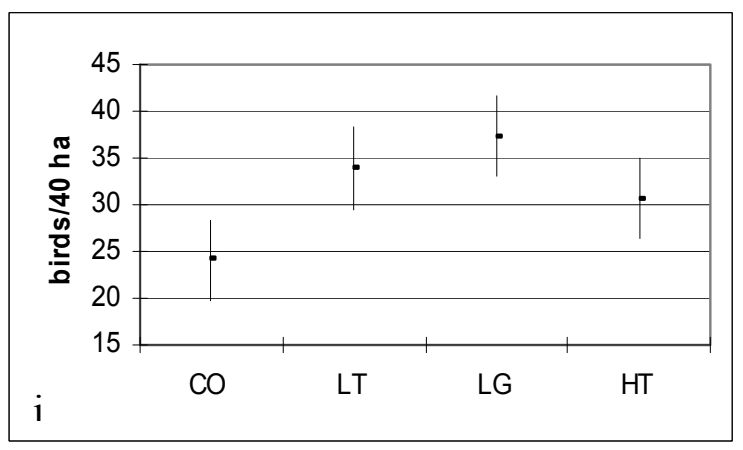

C. American Robin

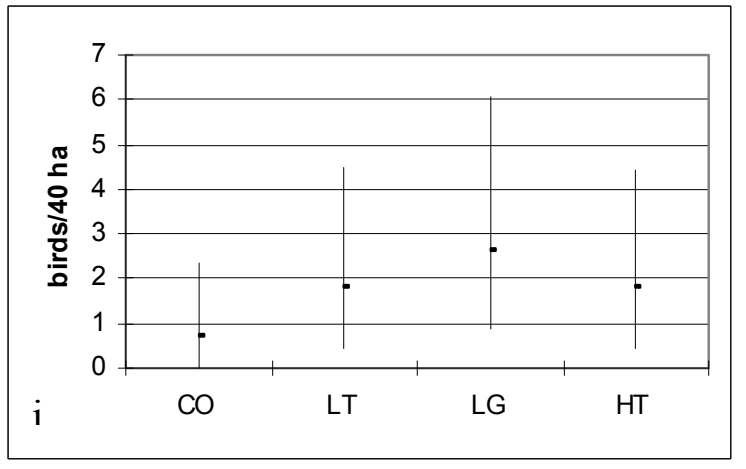

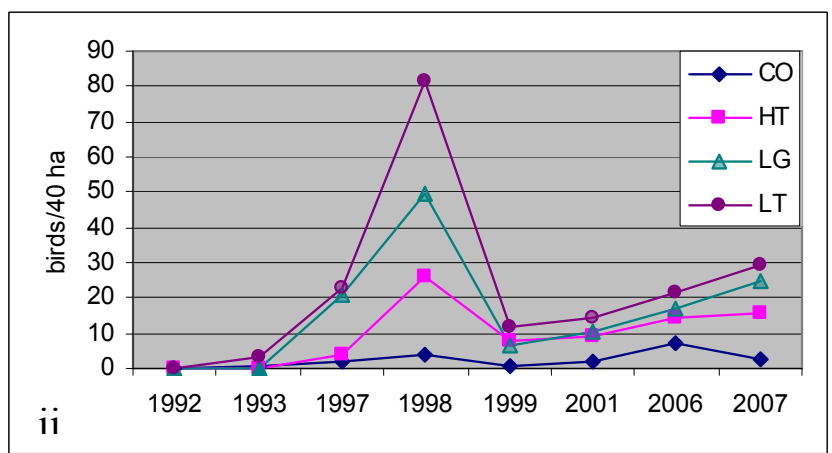
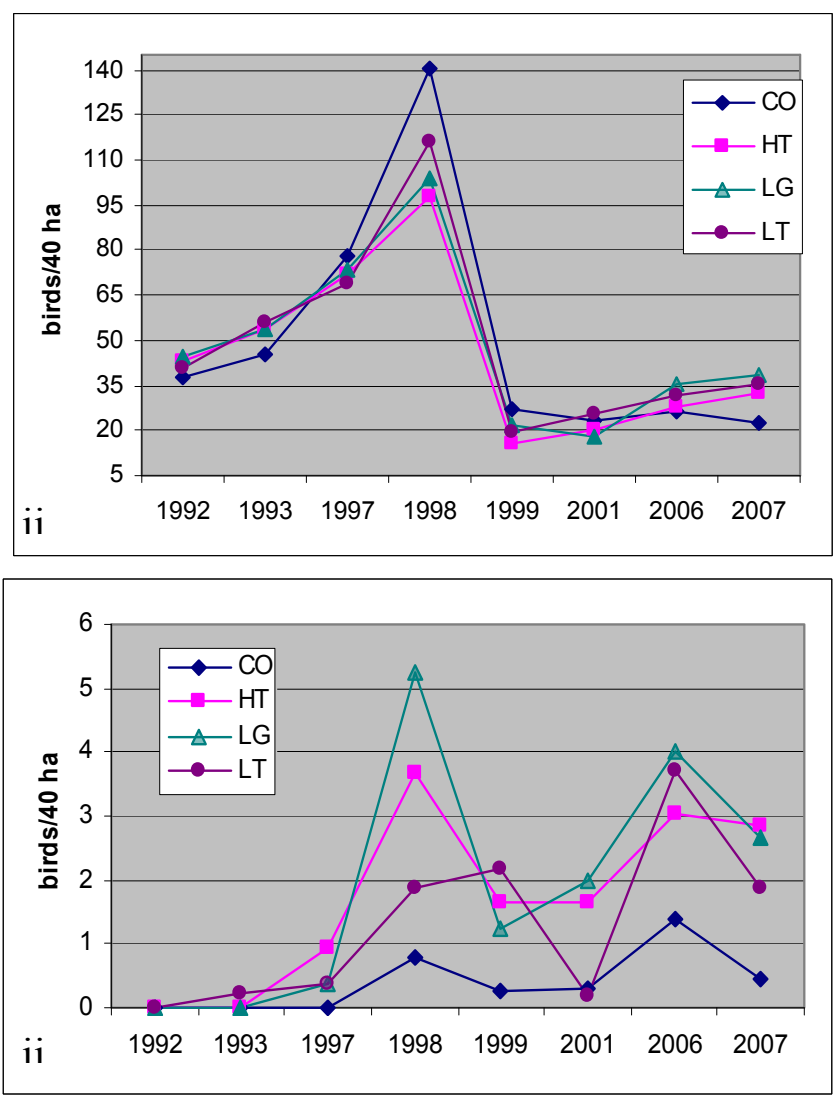

Figure 5. Comparison of density (birds/40 ha; with 90-percent confidence interval) in 2006-07 (i) and over 8 cumulative years of bird surveys (ii) for bird species showing a positive, threshold response to thinning in four silvicultural treatments in young Douglas-fir stands, Willamette National Forest, Oregon. [CO, unthinned controls, LT, light thin, LG, light thin with gaps, and heavy thin (HT)]. 


\section{MacGillivray's Warbler}

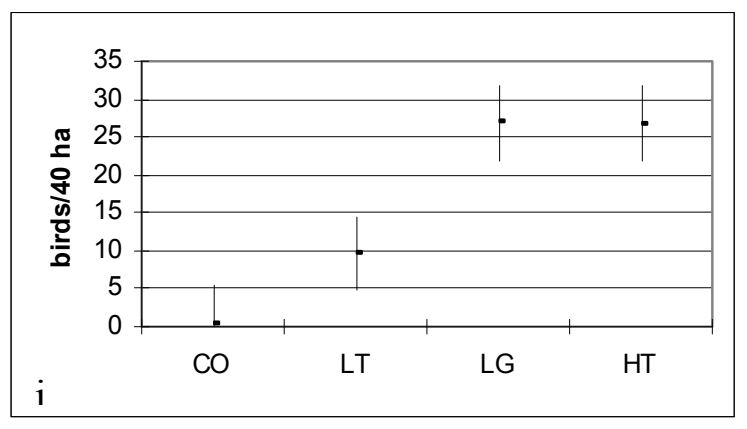

E. Swainson's Thrush

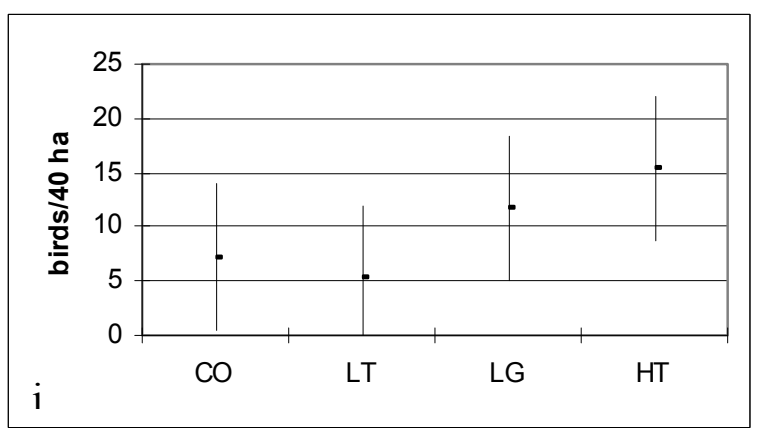

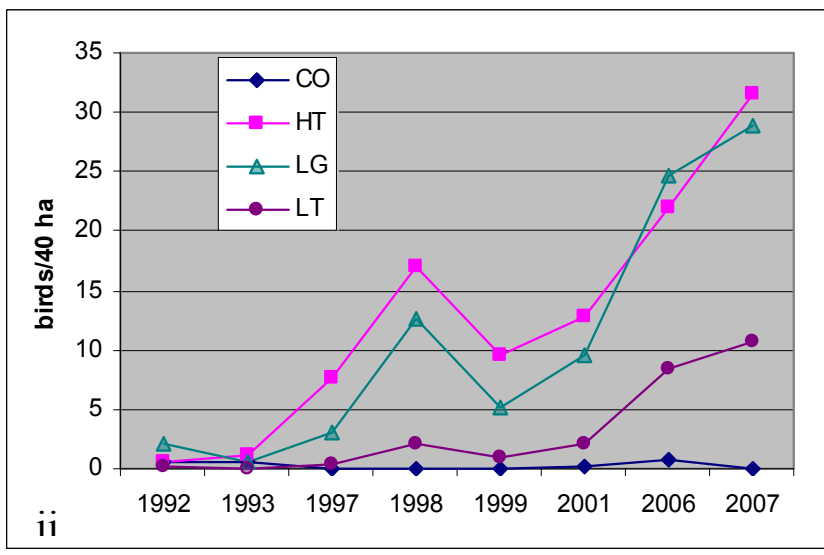

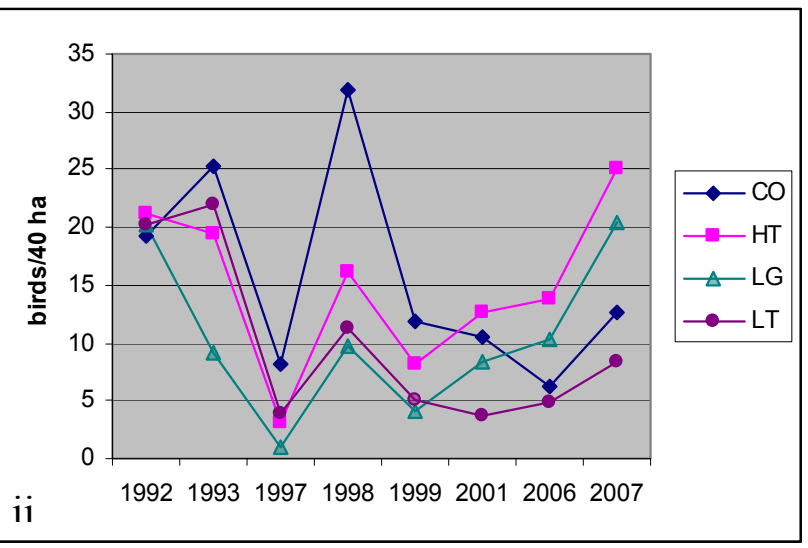

Figure 5.-Continued 
A. Golden-crowned Kinglet

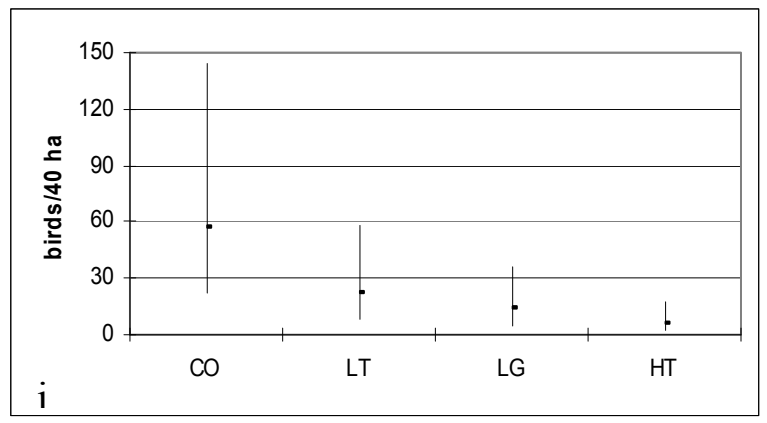

\section{B. Winter Wren}

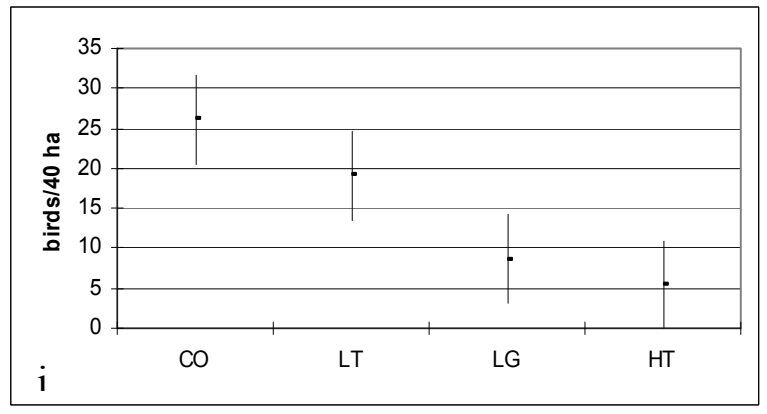

\section{Hermit Thrush}

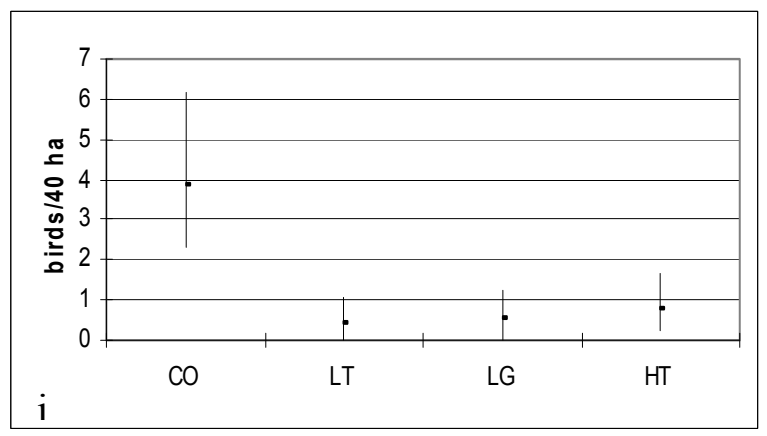

D. Pacific-slope Flycatcher

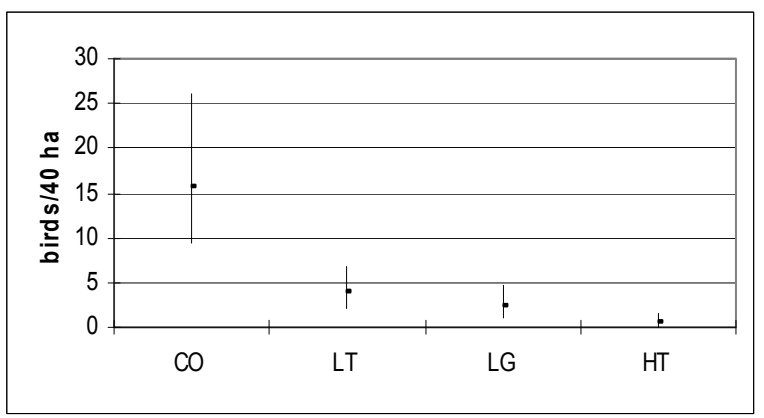

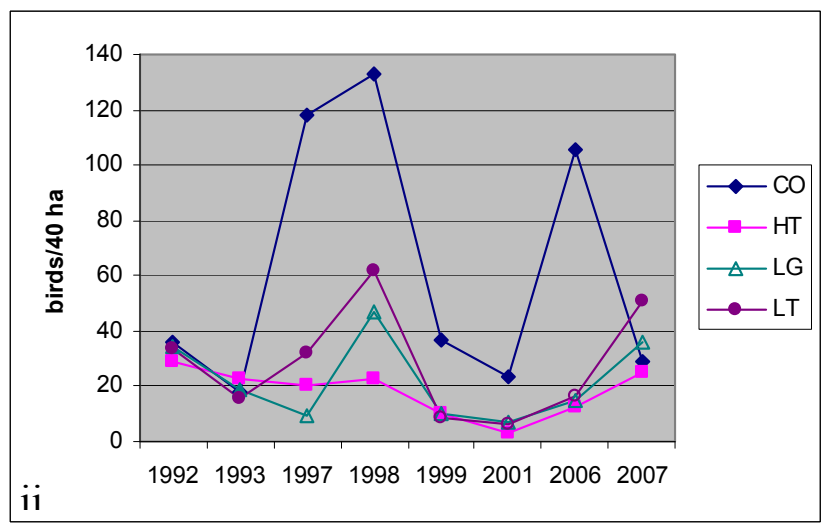
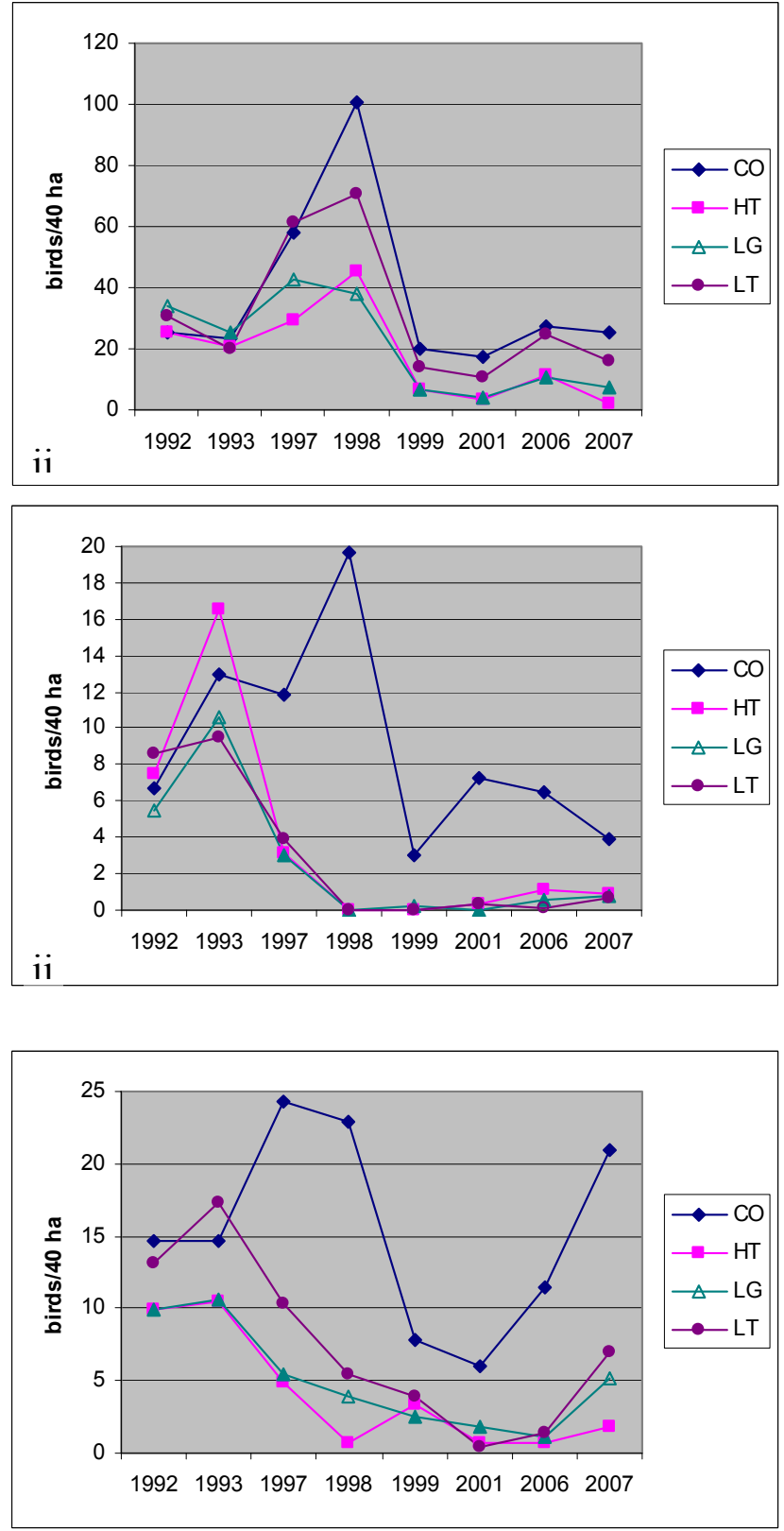

Figure 6. Comparison of density (birds/40 ha; with 90-percent confidence interval) in 2006-07 (i) and over 8 cumulative years of bird surveys (ii) for bird species showing a negative response to thinning in four silvicultural treatments in young Douglas-fir standsWillamette National Forest, Oregon. [CO, unthinned controls, LT, light thin, LG, light thin with gaps, and heavy thin $(\mathrm{HT})$ ]. 
Dark-eyed Junco and Western Tanager exhibited a positive, linear response to thinning in the 2006-07 survey period, with lowest densities in CO and highest in HT (fig. 4). Densities of Dark-eyed Junco and Western Tanager have been consistently greater in thinned than in CO stands throughout the post-treatment phase of the study, and have increased by at least an order of magnitude since the pretreatment phase (figs. 4.A.ii and 4.B.ii).

Densities of Hammond's Flycatcher, Hermit Warbler, American Robin, MacGillivray's Warbler, and Swainson's Thrush in the 2006-07 survey period varied with thinning intensity. Hammond's Flycatcher had highest densities in LT, whereas densities in LG and HT were more similar to densities in CO (fig. 5A.i.). This response pattern has been consistent throughout the post-treatment survey phase, but was most pronounced soon after thinning in 1998 (fig. 5A.ii.). Hermit Warblers also had higher densities in all thinned treatments than in CO in 2006-07, but densities in HT were less than in LT and LG (fig. 5B.i.). Hermit Warblers responded negatively to thinning in the first several years after thinning, and overall densities have been below those observed during the pretreatment period since 1999 (fig. 5.B.ii.). However, densities have been increasing in thinned stands since 1999, while remaining stable in CO. In 2006 and 2007, densities of Hermit Warblers in thinned stands approached pre-treatment levels, and exceeded those in $\mathrm{CO}$ for the first time.

Density of American Robins was greater in LG than CO stands, but density in HT and LT was similar to density in CO (fig. 5.C.i.). Density of Robins has consistently been greater in LG and LT than in $\mathrm{CO}$ throughout the post-thinning years of the study, and has remained above pre-treatment levels (fig. 5.C.ii.).

Densities of MacGillivray's Warbler and Swainson's Thrush in 2006-07 were greatest in LG and HT treatments, but did not differ between LT and CO (figs. 5C.i. and 5D.i.). Densities of MacGillivray's Warbler in HT and LG have increased substantially since thinning and are well above pre-treatment levels (fig. 5C.ii.). Similar to the Hermit Warbler, densities of Swainson's Thrush were greatest in CO stands in the early pre-treatment years, but have been increasing in HT and LG since 1999 (fig. 5D.ii.). The 2007 survey was the first in which Swainson's Thrush densities in HT and LG regained or exceeded pre-treatment levels.

A continued positive effect of thinning for two additional species that generally are uncommon on our study sites, Olive-sided Flycatcher and Spotted Towhee, was still evident one decade after harvest (table 3). Although these species were observed too infrequently to permit statistical analyses, we believe that their occurrence only in thinned stands during the post-harvest phase, compared to their rarity during the pre-harvest phase of the study, suggests a response to thinning treatments. For two other uncommon species, Common Nighthawk and Western Wood-pewee, the increase in the frequency of detection that was observed in thinned stands during the first post-harvest phase was no longer evident because these species were rarely detected in 2006 and 2007 (table 3).

Of the species that responded negatively to thinning, only the Golden-crowned Kinglet did not differ in density significantly between the LT treatment and CO in the 2006-07 survey period (fig. 6A.i). Golden-crowned Kinglet density in $\mathrm{CO}$ stands has shown wide annual variation, but was consistently higher than in thinning treatments throughout the years of the study until 2007 (fig. 6A.ii.). In 2007, kinglet density in LT and LG surpassed density in CO for the first time since stands were thinned, and exceeded pre-treatment densities. 
Table 3. Frequency of occurrence and (total number of observations) for uncommon species observed predominantly in thinned stands, Young Stand Thinning and Diversity Study, Cascade Range, Oregon.

\begin{tabular}{|l|l|l|l|l|}
\hline & $\begin{array}{c}\text { Pre-thinning } \\
(1992-93)\end{array}$ & \multicolumn{3}{|c|}{ (Phase I\&II: 1997-1999, 2001; Phase III: } \\
2006-07)
\end{tabular}

$* \mathrm{~N}$ is the total number of stand $\times$ year combinations possible for each treatment and phase combination.

Winter Wren, Hermit Thrush, and Pacific-slope Flycatcher had significantly lower densities in all three thinning treatments relative to CO. The density of Winter Wrens in the 2006-07 survey period was intermediate in LT compared to density in $\mathrm{CO}$ and the more intensively thinned treatments (LG and HT), but was still significantly lower in LT than in CO (fig. 6B.i.). The general pattern of greater density of Winter Wrens in CO and LT than in LG and HT has been consistent throughout the posttreatment survey (fig. 6B.ii.). Density of Winter Wrens in CO and LT in 2006 and 2007 was similar to the baseline density observed during the pre-treatment survey period. In contrast, densities of Hermit Thrush and Pacific-slope Flycatcher have not regained pre-treatment levels in thinned stands (figs. 6C.ii and 6D.ii.). However, Pacific-slope Flycatcher has shown an increasing trend in density in the last 3 survey years $(2001,2006,2007)$, with the greatest increases in the LT (fig. 6D.ii).

\section{Discussion}

The positive influence of thinning has persisted for at least a decade for seven species (Hammond's Flycatcher, Olive-sided Flycatcher, Western Tanager, MacGillivray's Warbler, Dark-eyed Junco, Spotted Towhee, and Red-breasted Sapsucker). The persistence of the positive effects of thinning for Hammond's Flycatcher, Olive-sided Flycatcher, and Western Tanager, suggest that even light thinning (for example, traditional commercial thin that reduces canopy cover by about 30 percent) maintains sufficient canopy openness for at least a decade to provide suitable habitat for some species associated with canopy gaps. This result would not have been expected based on the report that light thinning did not maintain openness of the canopy beyond 3 years (Davis and others, 2007). These bird species may be responding to more complex structural features of the canopy, such as variation in crown height, crown length, or foliage volume, that are not reflected in a simple estimate of canopy cover. For example, openness below tree crowns resulting from the removal of suppressed trees during thinning would benefit Hammond's Flycatcher (Hagar and others, 1996), which requires space beneath the canopy for foraging flights (Sedgwick, 1994). 
Open canopy conditions in thinned stands permit continued development of understory vegetation (Davis and Puettmann, in press), providing habitat for shrub-associated species such as MacGillivray's Warbler, Dark-eyed Junco, and Spotted Towhee. Density increases of MacGillivray's Warblers and Dark-eyed Juncos in thinned stands over the last 4 years of surveying may be paralleling understory development. As predicted, the most intensively thinned treatments, HT and LG, have maintained the highest densities of MacGillivray's Warblers and Dark-eyed Juncos.

The initial positive response of the Red-breasted Sapsucker and Hairy Woodpecker to thinning was thought to be related to an affinity for disturbed areas with wounded trees (Hagar and others, 2004). This response may have been prolonged by the creation of snags in 2001 . We had too few observations of Hairy Woodpeckers (16 in 2006; 17 in 2007) to reliably estimate density and test for an effect of thinning. However, considering that there were only a total of seven detections of this species during the 2 years of pre-treatment bird surveys, and that greater than 90 percent of the observations during 2006 and 2007 were in thinned stands, it seems reasonable to conclude that the positive effect of thinning on this species also has persisted.

The initial positive influence of thinning was no longer evident a decade after harvest for five species (Common Nighthawk, Western Wood-pewee, Townsend's Solitaire, Rufous Hummingbird, Gray Jay). Changes in the frequency of occurrence of Common Nighthawk may be attributable to changes in habitat availability as function of time since thinning. Benefits of thinning to the Common Nighthawk were not expected to last long because the bare ground exposed during thinning that this species uses for nesting (Altman, 2003) was rapidly colonized by early-seral perennials (Davis and Puettmann, in press). It is unclear if or how changes in stand structure since thinning may have influenced changes in density of the remaining four species. In 2006 and 2007, the densities of all these species reached their lowest levels since the pre-treatment phase of the study. Western Wood-pewees never were common on our study sites, but were present exclusively in thinned stands in the first few years following thinning. Townsend's Solitaires also never were abundant on our study sites, but occurred at a density of about $1-4$ birds/40 ha in thinned stands from immediately after thinning through 2006. In 2007, 11 of the 13 detections of Solitaires were in thinned stands, so the positive effect of thinning may have persisted, but was statistically undetectable at such low densities. The prediction that Western Wood-pewees and Townsend's Solitaires would persist in HT and LG stands, where suitable habitat is provided by gappy, uneven canopy structure (Hagar and others, 2004) was not supported. These two species possibly may have been attracted to an ephemeral resource, such as a flush of arthropod prey, which may have been available immediately after the disturbance of thinning. As with Townsend's Solitaires, the densities of Rufous Hummingbirds and Gray Jays decreased to levels too low for reliable estimation in 2006 and 2007, after having reached their highest levels in thinned stands in the first few years following harvest. It is unclear what factors may be driving population fluctuations of these species. Breeding bird survey data indicate regionally stable populations for Solitaires and Gray Jays, but statistically significant declines for Rufous Hummingbirds over the last decade (Sauer and others, 2008).

As vegetation developed in thinned stands over time, we expected to observe a recovery of some of the species that showed an immediate negative response to thinning. Of seven species with an initial negative response to thinning, Hermit Warbler, Golden-crowned Kinglet, and Swainson's Thrush are the first to indicate recovery towards pre-treatment densities. Hermit Warbler and Golden-crowned Kinglet forage for insects primarily in conifer canopies (Ingold and Gallati, 1997; Pearson, 1997), so may be influenced by a flush of crown growth in response to thinning (Davis and others, 2007). Crown development around the edges of gaps in the LG stands may have been particularly productive (Tappeiner and others, 2002), and availability of insect prey may have consequently increased in these habitats (Shure and Phillips, 1991). The combination of crown development and relatively continuous canopy cover in the LT treatment likely provides the most suitable habitat of the three thinning treatments for Golden-crowned Kinglets. 
The reversal of treatment effect on Swainson's Thrush density over the course of the study, from a negative effect immediately after harvest to a more recent positive effect (fig. 5.D.ii.), likely reflects development of understory vegetation. The Swainson's Thrush is strongly associated with shrubs, particularly tall, deciduous shrubs (Hagar, 2003). Therefore, the steady increase since 1999 in Swainson's Thrush density in HT and LG treatments may track the re-growth of understory vegetation during this period (Davis and Puettmann, in press). It is notable that density has remained lower in LT than CO stands. A possible explanation for this pattern is that the mechanical damage to shrubs during the thinning the operation (Davis and Puettmann, in press), resulted in a reduction in habitat suitability. Furthermore, the minimal reduction in canopy cover in LT stands may have been insufficient to promote the same level of understory development as seen in the more intensively treated HT and LG stands. Shrubs in CO stands would have remained undisturbed, but also suppressed by the dense overstory. Empirical data for these stands indicate that as of 2001, cover of low and tall shrubs did not differ statistically between thinned and CO stands, but that HT and LG stands averaged the highest cover of low shrubs, and that LT stands averaged the least cover of tall shrubs (Davis and Puettmann, in press). We predict that the HT and LG stands will continue to support the highest densities of Swainson's Thrushes indefinitely, in the absence of further disturbance, because shrub cover will likely continue to be greatest in these stands (Garman and others, 2002).

The other four species that showed a negative response to thinning in the first few years after harvest, Pacific-slope Flycatcher, Winter Wren, Varied Thrush, and Hermit Thrush (Hagar and others, 2004), have shown little indication of recovery to pre-treatment densities. A sharp decline in Pacificslope Flycatcher density, across all treatment types, masked the effect of treatment in the first several years following thinning (Hagar and others, 2004), but the most recent survey period (2006-07) confirmed a persistent negative treatment effect. As species associated with late-seral forests, Pacificslope Flycatcher, Winter Wren, and Varied Thrush (Gilbert and Allwine, 1991; Forest Ecosystem Management Assessment Team, 1993) were predicted to respond positively to thinning in the longterm, with the onset of structural features characteristic of old forests. A decade is likely insufficient time for the manifestation of this response. Therefore, we expect that more time is needed for the gap to close between densities of these species in thinned and un-thinned stands, and that LT stands will be the first to achieve this milestone. Although densities of Winter Wrens and Pacific-slope Flycatchers have remained fairly stable in all stands over the last 4 survey years, Varied Thrushes have become increasingly uncommon, even in CO stands. Overall decreases in the density of this species may be attributable to regional fluctuations in population size, rather than to local changes in habitat structure. According to (Breeding Bird Survey) BBS data, Varied Thrush populations have experienced a significant decline in the Cascade ecoregion over the last decade (Sauer and others, 2008). Future surveys will be needed to determine whether Varied Thrushes will colonize thinned stands once suitable habitat develops, assuming the species persists in this region.

Unlike the species mentioned above, Hermit Thrushes were predicted to be unlikely to recover after thinning (Hagar and others, 2004). This prediction has so far been supported. Canopy cover in thinned stands may be insufficient, and cover of understory vegetation too great, to be suitable habitat for the Hermit Thrush (see Nehls, 2003, for description of typical habitat in Oregon). Thinning has likely set stands on a trajectory that will not provide optimal habitat for this species in the foreseeable future. 


\section{Conclusions}

Both positive and negative effects on songbirds were still evident approximately one decade after thinning of 40-year-old Douglas-fir stands. The maintenance of higher densities or frequencies of detection in thinned than unthinned stands for most species that had an initial positive response to thinning, along with a reversal in the initial negative effects of harvest for three species, resulted in the persistence of higher species richness in thinned than unthinned stands. However, species in the management category "neotropical migrants" had widely varying responses to thinning, both initially and over time. This is not surprising, given the ecological diversity and range of habitat associations exhibited within this group, from open- to closed-canopy, open to shrubby understory, and coniferousto deciduous-associates. The disparity in responses to thinning among migrants indicates that management may need to consider the habitat needs of each species individually.

Canopy development over time since thinning has erased the statistical difference in overstory cover between LT and CO stands, but some canopy-dwelling bird species (for example, Hammond's Flycatcher) continue to respond to a treatment effect. This discrepancy in treatment effect from a habitat-measurement perspective versus an organism-response perspective highlights the importance of directly measuring the response of an organism of interest rather than assuming a response based on the habitat surrogate. In this case, conclusions based on vegetation measurements alone (effect of light thinning does not persist beyond 3 years) differ from those based on bird response (after one decade, light thinning maintains positive effect for some species and mitigates negative effect of thinning for others), and may yield different management recommendations. If the goals of thinning and other forest management activities include the maintenance or improvement of wildlife habitat, then directly monitoring wildlife response is critical.

\section{References Cited}

Altman, B., 2003, Common nighthawk, in Marshall, D., Hunter, M., Contreras, A., eds., The Birds of Oregon: A General Reference: Corvallis, Oregon, Oregon State University Press, p. 330-333.

Beavers, S.C., and Ramsey, F.L., 1998, Detectability analysis in transect surveys: Journal of Wildlife Management, v. 62, p. 948-957.

Burnham, K.P., and Anderson, D.R., 1998, Model selection and inference: A practical informationtheoretic approach: New York, Springer-Verlag.

Carey, A.B., 1998, Ecological foundations of biodiversity: lessons from natural and managed forests of the Pacific Northwest, in Trofymow, J.A., and MacKinnon, A., eds., Proceedings of a Workshop on Structure, Process and Diversity in Successional Forests of British Columbia, February 17-19, 1998: Victoria, BC., Northwest Science, v. 72 (Special Issue 2), p. 127-133.

Carey, A.B., Lippke, B.R., and Sessions, J., 1999, Intentional systems management: Managing forests for biodiversity: Journal of Sustainable Forestry, v. 9, n. 3/4, p. 83-125.

Davis, L.R., and Puettmann, K.J., in press, Initial response of understory vegetation to three alternative thinning treatments, Journal of Sustainable Forestry, v. 29.

Davis, L.R., Puettmenn, K.J., and Tucker, G.F., 2007, Overstory response to alternative thinning treatments in young Douglas-fir forests of western Oregon: Northwest Science, v. 81, p. 1-14.

DeBell, D.S., Curtis, R.O., Harrington, C.A., and Tappeiner, J.C., 1997, Shaping stand development through silvicultural practices, in Kohm, K.A., and Franklin, J.F., eds., Creating a Forest for the 21st Century: The Science of Ecosystem Management: Washington, DC, Island Press, p. 141-149.

Di Stefano, J., 2004, A confidence interval approach to data analysis: Forest Ecology and Management, v. 187, n. $2 / 3$, p. $173-183$. 
Forest Ecosystem Management Assessment Team (FEMAT), 1993, Forest Ecosystem Management: An Ecological, Economic, and Social Assessment, Report 1996-793-071: Washington, D.C., Forest Ecosystem Management Assessment Team, United States Government Printing Office.

Franklin, J.F., and Dyrness, C.T., 1988, Natural vegetation of Oregon and Washington: Oregon State University Press, Corvallis, Oregon.

Garman, S.L., 2000, Response of ground-dwelling vertebrates to thinning young stands: The Young Stand Thinning and Diversity Study, Interim report: Oregon State University, 35 p.

Garman, S.L., Cissel, J.H., and Mayo, J.H., 2002, Accelerating development of late-successional conditions in young managed Douglas-fir stands: A simulation study, PNW- GTR-557: Portland, OR, U.S. Department of Agriculture, Forest Service, Pacific Northwest Research Station.

Gilbert, F.F., and Allwine, R., 1991, Spring bird communities in the Oregon Cascade Range, in Ruggiero, L.F., Aubry, K.B., Carey, A.B., and Huff, M.F., eds., Wildlife and Vegetation of Unmanaged Douglas-fir Forests: Portland, Oregon, Proceedings of a Symposium on Old Growth Douglas-fir Forests: Wildlife Communities and Habitat Relationships, March 29-31, 1989, PNWGTR-285, U.S. Department of Agriculture, Forest Service, Pacific Northwest Research and Experiment Station, p. 145-158.

Hagar, J.C., 2003, Swainson's thrush Catharus ustulatus, in Marshall, D., Hunter, M., and Contreras, A., eds., Birds of Oregon: A general reference. Oregon State University Press, Corvallis, OR.

Hagar, J.C., McComb, W.C., and Emmingham, W.H., 1996, Bird communities in commercially thinned and unthinned Douglas-fir stands of western Oregon: Wildlife Society Bulletin, v. 24, p. 353-366.

Hagar, J.C., Howlin, S., and Ganio, L.M., 2004, Short-term response of songbirds to experimental thinning of young Douglas-fir forests in the Oregon Cascades: Forest Ecology and Management, v. 199, p. 333-347.

Hansen, A.J., Spies, T.A., Swanson, F.J., and Ohmann, J.L., 1991, Conserving biological diversity in managed forests: Bioscience, v. 41, p. 382-392.

Haveri, B.A., and Carey, A.B., 2000, Forest management strategy, spatial heterogeneity, and winter birds in Washington: Wildlife Society Bulletin, v. 28, p. 643-652.

Hayes, J.P., Weikel, J.M., and Huso, M., 2003, Effects of commercial thinning on breeding birds in the northern Coast Range of Oregon: Ecological Application, v. 13, p. 1222-1232.

Ingold, J.L., and Galati, R., 1997, Golden-crowned kinglet (Regulus satrapa) , in Poole, A., and Gill, F., eds., Birds of North America, No.301: Philadelphia, Pennsylvania, The Natural Academy of Science.

Nehls, H.B., 2003, Hermit thrush Catharus guttatus, in Marshall, D., Hunter, M., and Contreras, A., eds., Birds of Oregon: A general reference: Oregon State University Press, Corvallis, OR.

Pearson, S.F., 1997, Hermit Warbler (Dendroica occidentalis), in Poole, A., and Gill, F., eds., Birds of North America, No. 303: Philadelphia, Pennsylvania, The Natural Academy of Science.

Poage, N.J., 2000, Structure and development of old-growth Douglas-fir in central western Oregon: Corvallis, Oregon, Ph.D dissertation, Oregon State University.

Ralph, C.J., Droege, S., and Sauer, J.R., 1995, Managing and monitoring birds using point counts: standards and applications, in Ralph, C.J, Sauer, J.R., and Droege, S., eds., Monitoring Bird Populations by Point Counts, PSW-GTR-149: Albany, California, U.S. Department of Agriculture, Forest Service, Pacific Southwest Research Station, p. 161-175.

SAS Institute Inc., 2003, SAS/STAT user's guide, Version 9.1, SAS Statistical Institute, Cary, North Carolina, USA.

Sauer, J.R., Hines, J.E., and Fallon, J., 2008, The North American Breeding Bird Survey, Results and Analysis 1966 - 2007. Version 5.15.2008: USGS Patuxent Wildlife Research Center, Laurel, MD.

Sedgwick, J.A., 1994, Hammond's flycatcher (Empidonax hammondii) , in Poole, A., and Gill, F., eds., Birds of North America, No. 109: Philadelphia, Pennsylvania, The Natural Academy of Science.

Shure, D.J., and Phillips, D.L., 1991, Patch size of forest openings and arthropod populations:

Oecologia, v. 86, p. 325-334. 
Spies, T.A., Tappeiner, J., Pojar, J., and Coates, D., 1991, Trends in ecosystem management at the stand level: Transactions in North American Wildlife Natural Resources, Conf. 56, p. 628-639.

Steidl, R., Hayes, J.P., and Schauber, E., 1997, Statistical power analysis in wildlife research: Journal of Wildlife Management, v. 61, p. 270-279.

Tappeiner, J.C., Huffman, D.W., Marshall, D., Spies, T.A., and Bailey, J.D., 1997a, Density, ages, and growth rates in old-growth and young-growth forests in coastal Oregon: Canadian Journal of Forest Resources, v. 27, p. 638-648.

Tappeiner, J.C., Lavender, D., Walstad, J., Curtis, R.O., and DeBell, J.S., 1997b, Silvicultural systems and regeneration methods: current practices and new alternatives, in Kohm, K.A., and Franklin, J.F., eds., Creating a Forestry for the 21st Century: Washington D.C., Island Press, p. 151-164.

Tappeiner, J.C. II, Emmingham, W.H., and Hibbs, D.E., 2002, Silviculture of Oregon Coast Range forests, in Hobbs, S.D., Hayes, J.P., Johnson, R.L., Reeves, G.H., Spies, T.A., Tappeiner, J.C. II, and Wells, G.E., eds., Forest and stream management in the Oregon Coast Range: Corvallis, Oregon, Oregon State University Press, p. 172-190. 


\section{Appendix A. Scientific Names.}

\begin{tabular}{ll}
\hline \multicolumn{1}{c}{ Common Name } & \multicolumn{1}{c}{ Scientific Name } \\
\hline American robin & Turdus migratorius \\
Black-throated gray warbler & Dendroica nigrescens \\
Black-headed grosbeak & Pheucticus melanocephalus \\
Brown creeper & Certhia americana \\
Chestnut-backed chickadee & Poecile rufescens \\
Common nighthawk & Chordeiles minor \\
Dark-eyed junco & Junco hyemalis \\
Golden-crowned kinglet & Regulus satrapa \\
Gray jay & Perisoreus canadensis \\
Hammond's flycatcher & Empidonax hammondii \\
Hairy woodpecker & Picoides villosus \\
Hermit thrush & Catharus guttatus \\
Hermit warbler & Dendroica occidentalis \\
MacGillivray's warbler & Oporornis tolmiei \\
Northern flicker & Colaptes auratus \\
Olive-sided flycatcher & Contopus cooperi \\
Pileated woodpecker & Dryocopus pileatus \\
Pacific-slope flycatcher & Empidonax difficilis \\
Red-breasted nuthatch & Sitta canadensis \\
Red-breasted sapsucker & Sphyrapicus ruber \\
Rufous hummingbird & Selasphorus rufus \\
Spotted towhee & Pipilo maculatus \\
Steller's jay & Cyanocitta stelleri \\
Swainson's thrush & Catharus ustulatus \\
Townsend's solitaire & Myadestes townsendi \\
Varied thrush & Ixoreus naevius \\
Warbling vireo & Vireo gilvus \\
Western tanager & Piranga ludoviciana \\
Wilson's warbler & Wilsonia pusilla \\
Winter wren & Troglodytes troglodytes \\
Western wood-pewee & Contopus sordidulus \\
\hline
\end{tabular}


This page left intentionally blank 
Publishing support provided by the U.S. Geological Survey Publishing Network, Tacoma Publishing Service Center

For more information concerning the research in this report, contact the Director, Forest and Rangeland Ecosystems Science Center 777 NW 9th St., Suite 400

Corvallis, OR 97330

http://fresc.usgs.gov/ 


\section{总}

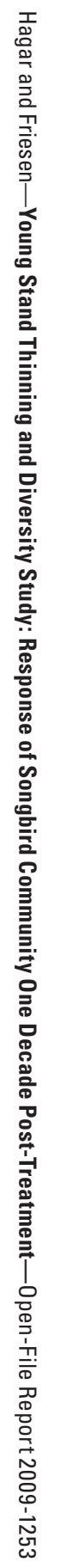

